\title{
イオンチャネルを標的とする殺虫性化合物の 電気生理学的研究
}

\author{
池田 朋子* \\ 筑波大学農林学系 \\ ノースウエスタン大学医学部分子薬理および生化学学科
}

(平成 14 年 5 月 20 日受理)

\section{Electrophysiological Study of the Mechanism of Action of Insecticides Activity on Ion Channels}

\author{
Tomoko IKEDA* \\ Institute of Agriculture and Forestry, University of Tsukuba, Tsukuba 305-8572, Japan \\ Department of Molecular Pharmacology and Biological Chemistry, Northwestern University Medical School, \\ Chicago, IL 60611, U.S.A.
}

Key words: GABA receptor, nACh receptor, fipronil, picrotoxinin, anisatin, patch clamp, ion channel.

\section{は じめに}

イオンチャネルは細胞膜上に存在している膜貫通型の夕 ンパクで, 神経系における情報伝達機構に重要な役割を 担っている．イオンチャネルの中央には孔 (pore) が形成さ れており，イオンがこの孔を通って移動することにより， 細胞膜電位が変化する. 神経軸策上の活動電位は, $\mathrm{Na}^{+}$ チャネルおよび $\mathrm{K}^{+}$チャネルの開閉により伝達され, シナ プス間隙においては, 神経伝達物質の GABA やアセチル コリン等が前膜から放出され後膜に存在するレセプターに 結合することによりチャネルが開口し刺激が伝達される。

今日までに開発された殺虫剂の中には，これらイオン チャネルを作用点とするものが多くある．本研究では特に $\mathrm{GABA}_{\mathrm{A}}$ レセプターチャネル複合体 $\left(\mathrm{GABA}_{\mathrm{A}}\right.$ レセプター) およびニコチン性アセチルコリン受容体（nAChレセプ ター）に作用する殺虫片および天然化合物に注目した。

$\mathrm{GABA}_{\mathrm{A}}$ レセプターは陰イオンである $\mathrm{Cl}^{-}$透過型のイオ ンチャネルであり, 抑制性神経伝達を引き起こす。一方,

\footnotetext{
* To whom correspondence should be addressed to this author.

E-mail: t-ikeda@ northwestern.edu
}

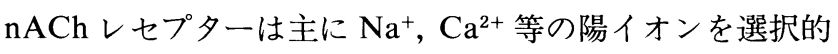
に透過し, 興奮性神経伝達に関与するイオンチャネルであ る.いずれのレセプターも5つのサブュニットが集合して 中央にイオンを透過させる穴を形成している。

薬剂の神経系に対する作用機構を解明する手段として, 標識イオンの細胞内への取り込み測定実験, 放射性標識リ ガンドの特異的結合の解析，および神経細胞に薬物を処理 して応答を調べる電気生理学的手法がある．電気生理学的 手法では，薬剤の作用により引き起こされるチャネル機能 変化を電流の変化としてとらえる.チャネル機能変化はミ リ秒単位で起きることが多いので, 電気生理学的手法は薬 剂・イオンチャネル間の相互作用を解析する上で最も適し た手段といえる. 本研究で用いた電気生理学的手法のパッ チクランプ法は, 単一チャネルにおける応答をとらえるこ とが可能な手段として 1976 年に Neher と Sakmannによ ク開発された ${ }^{11}$.これは以前に開発された電位固定法の一 つの変形で, 膜電位の変化に伴う電流を測定することによ クチャネル機能を解析するものである. ホールセル法およ びシングルチャネル法があり, ホールセル法では単一細胞 上に存在している全てのチャネルを通過するイオン電流の 総和を測定する.シングルチャネル法は単一チャネルを通 
過するイオン電流を測定する方法で，個々のイオンチャネ ルの電流伝導度（コンダクタンス）の変化，開時間および 閉時間の変化が測定できる.

本研究では, $\mathrm{GABA}_{\mathrm{A}} レ$ レ゚ターに対し抑制的に作用す る化合物に注目し，フェニルピラゾール系殺虫剂フィプロ ニル，有機塩素系殺虫剂ディルドリン，さらに，植物由来 の天然毒アニサチンの作用機構をパッチクランプ法を用い て解明した。そしてこれまでに多くの知見が得られている ピクロトキシニンの作用と比較し, 結合部位についても検 討した. また, nAChレセプタ一に作用する殺虫剂, カル タップ，およびネオニコチノイド系殺虫剤ニテンピラムの 作用機構をシングルチャネル法を用いて検討した。

\section{フィプロニルの $\mathrm{GABA}_{\mathrm{A}}$ レセプターに対する作用}

GABA 誘導性イオン電流に対するフィプロニルの作用 を，ホールセルパッチクランプ法で調べた. 神経標本とし て，ラット脊椎に存在する背根神経節細胞 (dorsal root ganglion neuron; DRG ニューロン) を一次培養して用い た. イオン電流は細胞膜電位を $-60 \mathrm{mV}$ に固定し $300 \mu \mathrm{M}$ の GABA を $10 \mathrm{msec}, 1$ 分間隔で繰り返し処理して誘導した (Fig. 1A).GABA 処理によりチャネルが開ロし， $\mathrm{Cl}^{-}$の細 胞外流出に伴う内向きイオン電流が発生した. Fig. 1Bに電 流ピーク值の経時変化を示す.フィプロニル $1 \mu \mathrm{M} を$ 外液に 溶解して細胞に処理すると, 電流は次第に抑制されコント

A

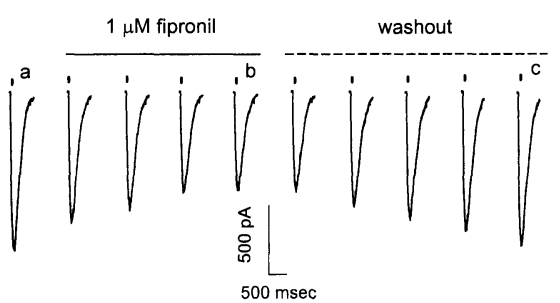

B

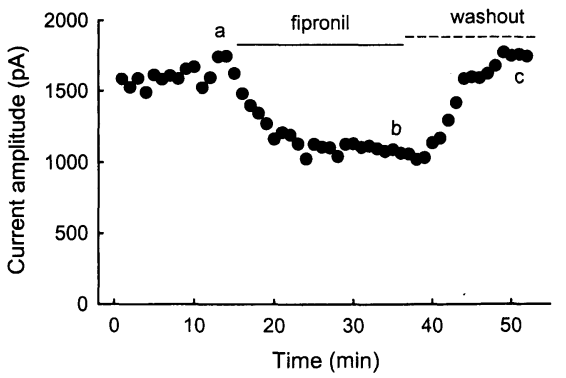

Fig. 1. Suppression of GABA-induced currents by fipronil in a rat DRG neuron.

(A) Current records in response to $10 \mathrm{msec}$ applications of $300 \mu \mathrm{M}$ GABA before (a), during (b) and after (c) application of $1 \mu \mathrm{M}$ fipronil in the bath. (B) Time course of changes in peak current amplitude before, during and after application of $1 \mu \mathrm{M}$ fipronil. Letters a to c correspond to those in $\mathrm{A}$.
ロールの $66.1 \pm 8.1 \%$ となた。外液からフィプロニルを除 くとイオン電流は回復したことから，フィプロニルによる 電流抑制は可逆的であることが判明した ${ }^{2)}$.

ある種のチャネル内部に作用する化合物ではチャネルの 活性化によりその作用が変化することが知られている. 従って，チャネルの活性化とフィプロニルの作用について 検討した.ここで活性化チャネルとは GABA 処理により 開閉を繰り返しているチャネルを，静止チャネルとは閉じ た状態のチャネルを示す。フィプロニルの静止チャネルに 対する作用を検討するため, GABA 処理を中断してフィプ ロニルを前処理し抑制の有無を調べた.フィプロニル前処 理後 15 分経過したイオン電流はコントロールの $68.4 \pm$ 9.3\%であった 2 . このことからフィプロニルによる電流抑 制は静止状態のチャネルにおいても同様に観察されること が示された。

さらにフィプロニルの作用を静止チャネルと活性化チャ ネルにおいて比較した. Fig. 2 はフィプロニルと静止チャ ネルおよび活性化状態のチャネルとの相互作用を表した模 式図である。 R は静止千ャネル, G は GABA 分子, R*G は GABA が結合したことにより活性化されたチャネル， RF はフィプロニルが作用した静止チャネル， $\mathrm{R}^{*} \mathrm{GF}$ はフィプ ロニルが作用した活性化チャネルを示す． $\mathrm{k}_{+1}$ および $\mathrm{k}_{-1}$ はそれぞれ静止チャネルにおける薬剤の結合速度および解 離速度を表す。 $\mathrm{k}_{+1}^{\prime}$ および $\mathrm{k}_{-1}$ はそれぞれ活性化チャネル における薬剤の結合速度および解離速度を表す。

静止チャネルにおけるフィプロニルの作用を調べるため

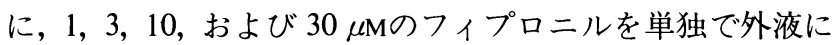
処理し，抑制を測る目的で $300 \mu \mathrm{M}$ の GABAを 10 秒間隔で $10 \mathrm{msec}$ 処理した. 電流はフィプロニル処理時間と濃度依存 的に抑制された。結合速度と解離速度を求めるために，電 流のピーク值の変化をフィプロニル処理時間に対してプ ロットし，一次の指数関数曲線で近似した (Fig. 3A). 時定 数 $(\tau)$ の值は $1,3,10$ および $30 \mu \mathrm{M}$ のフィプロニルを処理

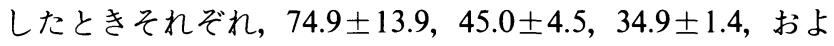

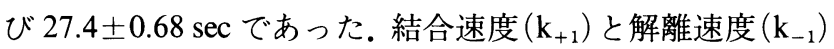

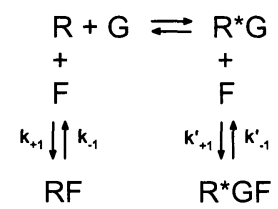

Fig. 2 Fipronil interaction with both the resting and activated $\mathrm{GABA}_{\mathrm{A}}$ receptors.

$R$, resting receptor; $G, G A B A ; R^{*} G$, the receptor bound and activated by GABA; F, fipronil; RF, the fipronil-bound resting receptor; $R^{*} \mathrm{GF}$, the fipronil-bound activated receptor; $\mathrm{k}_{+1}$ and $\mathrm{k}_{-1}$, drug association and dissociation rates, respectively, without GABA; and $\mathrm{k}_{+1}^{\prime}$ and $\mathrm{k}^{\prime}{ }_{-1}$, drug association and dissociation rates, respectively, with GABA. 
をモデルに従った等式 $1 / \tau=\mathrm{k}_{+1}[\mathrm{~F}]+\mathrm{k}_{-1}$ より求めるため, $\tau$ の逆数をフィプロニル濃度でプロットした結果, $\mathrm{k}_{+1}$ は $673 \pm 220 \mathrm{M}^{-1} \mathrm{sec}^{-1}, \mathrm{k}_{-1}$ は $0.018 \pm 0.0035 \mathrm{sec}^{-1}$ の值が求めら れた (Fig. 3B).

次に活性化チャネルにおけるフィプロニルの電流抑制を 検討するため， 1，3，10 および $30 \mu \mathrm{M}$ のフィプロニルと 30 $\mu \mathrm{M} の \mathrm{GABA}$ を 30 秒間同時処理した (Fig. 4A). イオン電 流の下降相は処理時間および処理濃度依存的に強く現れ た. 電流の下降相を一次の指数関数曲線で近似し, $\tau$ 值はそ

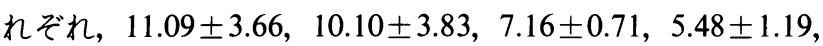

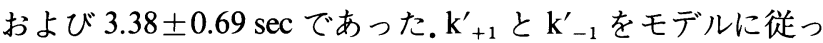
た等式 $1 / \tau=\mathrm{k}_{+1}[\mathrm{~F}]+\mathrm{k}_{-1}$ より求めるため, $\tau$ の逆数をフ、 プロニル濃度でプロットした結果， $\mathrm{k}^{\prime}{ }_{+1}$ は $6600 \pm 380 \mathrm{M}^{-1}$
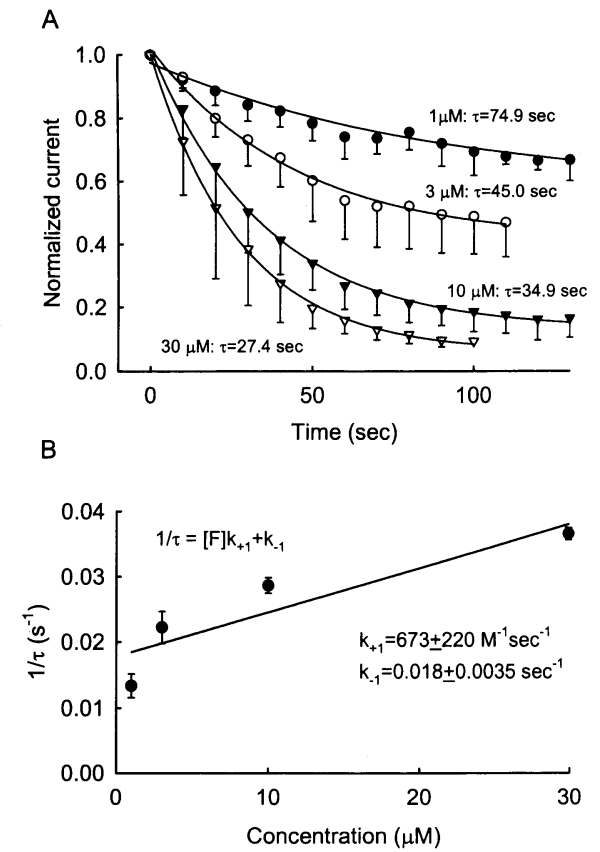

Fig. 3 Kinetics of fipronil suppression of the resting GABA receptor in a rat DRG neuron.

Decreases in currents induced by various concentrations of fipronil during bath application are plotted as a function of incubation period. GABA pulses $(300 \mu \mathrm{M}, 10 \mathrm{msec})$ were applied every $10 \mathrm{sec}$ to monitor the change in current amplitude. (A) Time course of decrease in peak current amplitude by bath application of fipronil at $1,3,10$, and $30 \mu \mathrm{M}$ for $100-150 \mathrm{sec}$. Changes in current amplitude relative to the first current amplitude are plotted as a function of incubation period for each fipronil concentration, and the plots are fitted with a single exponential function. (B) The reciprocal of the time constants obtained from a single exponential fitting is plotted as a function of fipronil concentration. The solid line represents the relation $1 / \tau=\mathrm{k}_{+1}[\mathrm{~F}]+\mathrm{k}_{-1}$. The fit was less satisfactory since the correlation coefficient was 0.89 with a degree of freedom of 2 . The association and dissociation rates for fipronil interacting with the resting receptor are calculated to be $\mathrm{k}_{+1}=673 \pm 220 \mathrm{M}^{-1} \mathrm{sec}^{-1}$ and $\mathrm{k}_{-1}=0.018 \pm 0.0035 \mathrm{sec}^{-1}$, respectively. $\mathrm{sec}^{-1}, \mathrm{k}_{-1}^{\prime}$ は $0.11 \pm 0.0054 \mathrm{sec}^{-1}$ であった (Fig. 4B). 不活 性チャネルにおける場合と比較すると, GABAによるチャ ネル活性化により,フィプロニルの結合速度は 9.8 倍, 解離 速度は 6.2 倍に増加したことがわかる.

さらに定常状態での作用を比較するため，静止チャネル および活性化チャネルにおけるフィプロニルの薬量作用曲 線から半抑制濃度を測定した結果，静止チャネルでは $1.66 \pm 0.18 \mu \mathrm{M}$ ，活性化チャネルでは $1.61 \pm 0.14 \mu \mathrm{M}$ とな た.互いの值は近似していたことから，フィプロニルの定 常状態での抑制は，チャネルの開閉に関わらず一定の值を 示すことが判明した。

以上のことから，フィプロニルは静止チャネルにも作用

A
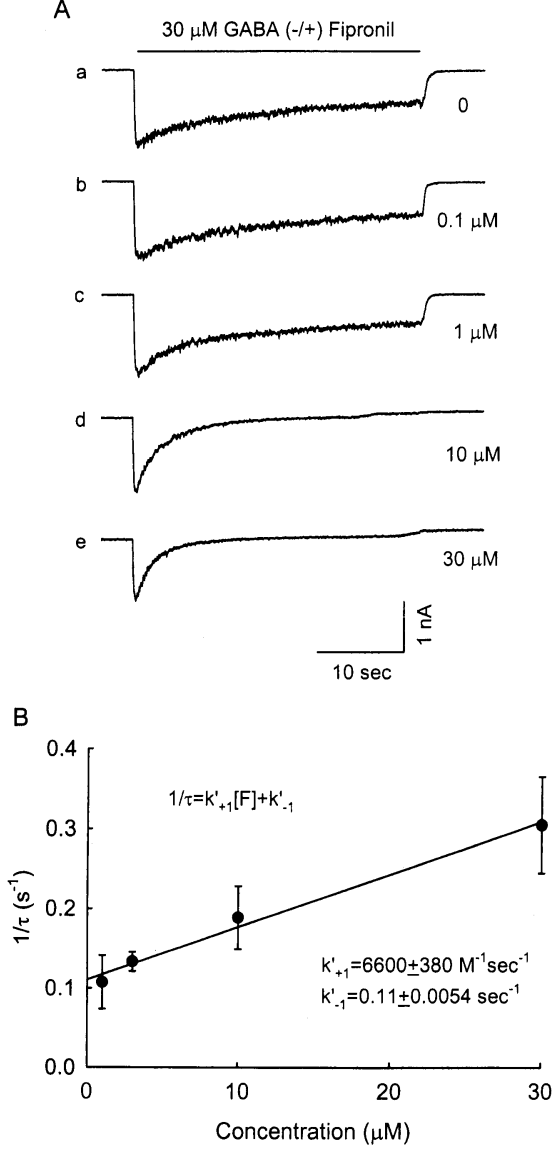

Fig. 4 Effects of fipronil at various concentrations on the decay phase of currents induced by long applications of GABA in a rat DRG neuron.

(A) GABA $30 \mu \mathrm{M}$ was applied for $30 \mathrm{sec}$ to induce currents, and was co-applied with various concentrations of fipronil. The decay phase of currents was fitted with a single exponential function to obtain time constants. (B) The reciprocal of the time constants $(1 / \tau)$ plotted as a function of fipronil concentration. Data points are best fitted to the solid line according to the equation $1 / \tau=\mathrm{k}^{\prime}{ }_{1}[\mathrm{~F}]+\mathrm{k}^{\prime}{ }_{-1}$. The correlation coefficient of 0.995 gives a significant level of $\mathrm{P}<0.05 . \quad \mathrm{k}_{+1}=6600 \pm 380 \mathrm{M}^{-1} \mathrm{sec}^{-1} ; \quad \mathrm{k}_{-1}=0.11 \pm 0.0054$ $\sec ^{-1}$. 
するが, チャネルの活性化に伴いフィプロニルの抑制と抑 制からの回復は促進することが判明した．しかし，定常状 態における抑制に関しては, チャネルの活性化に伴う変化 は認められなかった.チャネルの活性化に伴いフィプロニ ルによる抑制と抑制からの回復が促進された現象はピクロ トキシニンにおいても報告されている3).フィプロニルの 結合部位がピクロトキシニンと同様にチャネル内面である とすると，チャネル開口に伴いフィプロニルの結合部位へ の接近が容易になったと考えると説明がつく。

\section{アニサチンの GABA $\mathrm{A}_{\mathrm{A}}$ レセプターに対する作用}

アニサチンはモクレン科に属する Illicium anisatium (シ キミ)に含有される有毒成分である ${ }^{4-6)}$. アニサチンの作用 に関する研究は生化学的および電気生理学的手法を用いて 行われ，アニサチンは GABAの作用を阻害する化合物で あると報告された ${ }^{7-9)}$. しかしこれまでにアニサチンに関す るイオンチャネルレベルでの研究は行われていない.ここ ではラットDRGニューロンを用いてアニサチンの $\mathrm{GABA}_{\mathrm{A}}$ レセプターにおける作用機構をホールセルパッチ クランプ法を用いて検討した。

Fig. 5 はアニサチンの GABA 誘導性電流に対する抑制 を示している. A は測定したイオン電流の図で, Bにその時 の経時変化を示した．細胞の膜電位を $-60 \mathrm{mV}$ に固定して
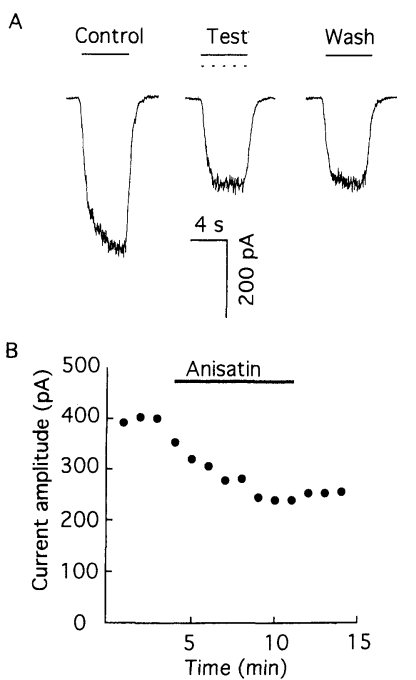

Fig. 5 Suppression of GABA-induced currents by coapplication of anisatin and GABA in a rat DRG neuron. (A) Current records in response to $5 \mathrm{sec}$ application of 30 $\mu \mathrm{M}$ GABA with and without anisatin. GABA alone (solid bar); co-application of GABA and anisatin (broken bar). (B) Time course of changes in peak current amplitude by repeated applications of GABA alone and co-application of GABA and anisatin (solid line). The peak amplitude of current gradually decreased during repeated co-applications. No recovery was observed after washing with anisatin-free solution.

$30 \mu \mathrm{M} の \mathrm{GABA}$ を $5 \mathrm{sec}$ 処理すると, 内向き電流が発生し た.GABAのみを処理したコントロールと比較して, $1 \mu \mathrm{M}$ のアニサチンを GABA と同時处理するとイオン電流は抑 制され，アニサチンを除いても抑制から回復しなかった。 このことからアニサチンによる抑制は不可逆的であること が判明した ${ }^{10)}$.

さらに，アニサチンの静止チャネルに対する作用を検討

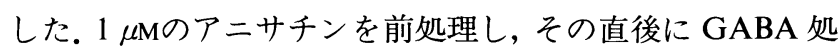
理により誘導された電流を測定した．アニサチン処理前後 で電流の大きさに有意差は認められなかったことから，ア ニサチンが作用を示すためには, GABAによるチャネルの 活性化が必要であることが判明した ${ }^{10}$.

\section{各種化合物の GABA 誘導性シングルチャネル イオン電流に対する作用}

殺虫剂のイオンチャネルに対する作用を検討する上で, シングルチャネル法を適用した例は少ない。各種化合物の 詳細な作用機構を検討するため, シングルチャネルパッチ クランプ法を用いて単一チャネルに対する作用を比較し た. 膜電位を $-60 \mathrm{mV}$ に固定したアウトサイドアウトの パッチ膜に, $10 \mu \mathrm{m}$ の GABA を外液に処理すると, 内向き のシングルチャネル電流が発生した (Fig. 6). A はコント ロールでGABAを単独で処理した時に観察されたもの,

$\mathrm{B}, \mathrm{C}, \mathrm{D}, \mathrm{E}$ はそれぞれ $10 \mu \mathrm{M}$ フィプロニル，1 $\mu \mathrm{M}$ アニサチ

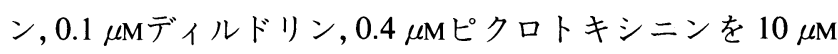
の GABA と同時処理した結果得られた電流である. シン グルチャネル電流は単独の開口あるいはバーストを形成し

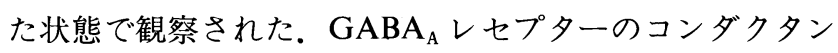
スは少なくとも 4 つの段階が知られており，それらは 26 $\mathrm{pS}$ のメインコンダクタンス, 11 および $19 \mathrm{pS}$ のサブコンダ クタンス, $44 \mathrm{pS}$ のスープラコンダクタンスである ${ }^{11}$. 本研

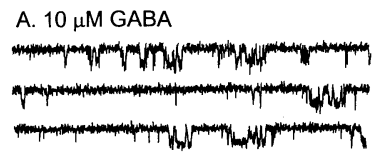

B. $+10 \mu \mathrm{M}$ fipronil

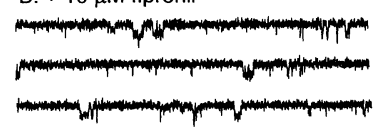

C. $+1 \mu \mathrm{M}$ anisatin

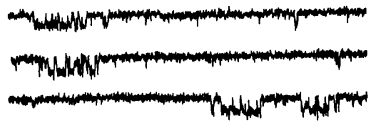

Fig. 6 Single-channel currents induced by application of 10 $\mu \mathrm{M}$ GABA (A) and co-application of $10 \mu \mathrm{M}$ GABA and 10 $\mu \mathrm{M}$ fipronil (B), $1 \mu \mathrm{M}$ anisatin (C), $0.1 \mu \mathrm{M}$ dieldrin (D), or $0.4 \mu \mathrm{M}$ picrotoxinin (E) to outside-out membrane patches isolated from rat DRG neurons. Membrane potential was held at $-60 \mathrm{mV}$. 
Table 1 Summary of Modulation of GABA-induced single-channel and whole-cell currents by chemicals.

\begin{tabular}{|c|c|c|c|c|c|}
\hline & $\begin{array}{l}\text { Open } \\
\text { time }\end{array}$ & $\begin{array}{l}\text { Closed } \\
\text { time }\end{array}$ & $\begin{array}{l}\text { Open } \\
\text { probability }\end{array}$ & $\begin{array}{l}\text { Whole-cell } \\
\text { current }\end{array}$ & \\
\hline Fipronil & $\downarrow$ & $\uparrow \uparrow$ & $\downarrow \downarrow$ & $\downarrow$ & \\
\hline Anisatin & NO & $\uparrow \uparrow$ & $W$ & $\downarrow$ & \\
\hline Dieldrin & $\downarrow$ & $\uparrow \uparrow$ & $\downarrow$ & $\downarrow t$ & $\begin{array}{l}\text { Increase } \\
\text { Decrease }\end{array}$ \\
\hline Picrotosinin & No & $\uparrow \uparrow$ & $\downarrow \downarrow$ & $\downarrow \downarrow$ & No change \\
\hline
\end{tabular}

究においてはサブコンダクタンスはまれにしか観察されな かったので，26 pSのメインコンダクタンスのみを解析し た. GABAのみを処理した場合, メインコンダクタンスは $27.2 \pm 4.3 \mathrm{pS}$ であった. GABA とフィプロニル，アニサチ ン，ディルドリン，および，ピクロトキシニンを同時処理 したときのメインコンダクタンスはそれぞれ，26.1 24.1

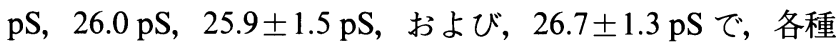
化合物処理によりチャネルのコンダクタンスの大きさは変 化せず，サブコンダクタンスの発生頻度も GABA 単独処 理の場合と同様に極めて低かったことから，各種化合物は チャネルのコンダクタンスを変化させる作用はないことが 判明した ${ }^{10,12)}$.

さらにチャネルの開時間および閉時間について解析し た結果を Table 1 にまとめた。各種化合物は共通してチャ ネルの平均閉時間を延長した ${ }^{10,12)}$. 従って, これらの化合物 は共通してチャネルの開頻度を低下させ，チャネルを閉じ た状態で安定化させる作用があると言える.さらに，ディ ルドリンおよびフィプロニルはチャネル平均開時間を減少 させる作用もあり，これらのシングルチャネルパラメター 変化がホールセルイオン電流抑制機構であると考えられ る.

\section{結 合 部 位}

$\mathrm{GABA}_{\mathrm{A}}$ レセプターにはいくつかの薬剤作用点が存在す る. GABA の作用を非競合的に阻害するピクロトキシニン は $\mathrm{GABA}_{\mathrm{A}} レ$ レプター上に結合部位を持ち GABA の作用 を阻害する多くの化合物が同部位に結合すると報告されて いる ${ }^{13)}$.ディルドリンはピクロトキシニンと結合部位を共 有すると言われており ${ }^{14,15)}$ ，フィプロニルの結合部位に関 しても，ピクロトキシニンやディルドリンと同一であると いう報告がある ${ }^{16,17)}$. また, アニサチンの結合部位を電気生 理学的に検証した例は報告されていない.

\section{1. フィプロニルとピクロトキシニンとの間の相互作用}

フィプロニルの結合部位を検証するため, フィプロニル

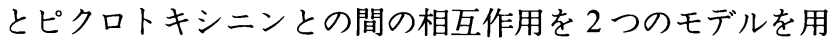
いて検討した $(\text { Fig. 7 })^{2)}$. 1 site model ではピクロトキシニ ンとフィプロニルは同一部位に結合し， 2 site model では

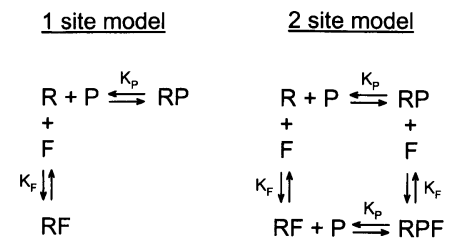

Fig. 7 One-site model and two-site model for interactions of fipronil (F) and picrotoxinin (P) with the $\mathrm{GABA}_{\mathrm{A}}$ receptor $(\mathrm{R})$.

$\mathrm{RF}$, fipronil-bound receptor; RP, picrotoxinin-bound receptor; RPF, picrotoxinin- and fipronil-bound receptor; $\mathrm{K}_{\mathrm{F}}$ and $K_{P}$, the equilibrium dissociation constants for fipronil and picrotoxinin binding, respectively.

フィプロニルとピクロトキシニンは独自の部位に結合する と仮定する．従って，1 site model では，フィプロニルおよ びピクロトキシニンの抑制は結合部位にピクロトキシニン またはフィプロニルが結合した RP と RF の和で表される (eq. 1). 2 site model においては，フィプロニルとピクロト キシニンはそれぞれ独自の結合部位を持つことから，両化 合物による抑制は，ピクロトキシニンまたはフィプロニル が結合した RP， RF，さらにピクロトキシニンおよびフィ プロニルが結合した RPF の和で表される (eq. 2).

$\mathrm{RP}+\mathrm{RF}=\mathrm{R}_{\mathrm{T}}\left([\mathrm{P}] / \mathrm{K}_{\mathrm{P}}+[\mathrm{F}] / \mathrm{K}_{\mathrm{F}}\right) /\left(1+[\mathrm{P}] / \mathrm{K}_{\mathrm{P}}+[\mathrm{F}] / \mathrm{K}_{\mathrm{F}}\right)$ (eq. 1)

$\mathrm{RP}+\mathrm{RF}+\mathrm{RPF}=\mathrm{R}_{\mathrm{T}}\left([\mathrm{P}] / \mathrm{K}_{\mathrm{P}}+[\mathrm{F}] / \mathrm{K}_{\mathrm{F}}+[\mathrm{P}][\mathrm{F}] / \mathrm{K}_{\mathrm{P}} \mathrm{K}_{\mathrm{F}}\right)$ $/\left(1+[\mathrm{P}] / \mathrm{K}_{\mathrm{P}}+[\mathrm{F}] / \mathrm{K}_{\mathrm{F}}+[\mathrm{P}][\mathrm{F}] / \mathrm{K}_{\mathrm{P}} \mathrm{K}_{\mathrm{F}}\right)$

(eq. 2)

$\mathrm{R}_{\mathrm{T}}$ は測定している細胞の膜上に存在する全 $\mathrm{GABA}_{\mathrm{A}} レ セ$ プターを， $[\mathrm{P}]$ と $[\mathrm{F}]$ はピクロトキシニンとフィプロニル の濃度を示す. $\mathrm{K}_{\mathrm{F}}$ および $\mathrm{K}_{\mathrm{P}}$ 值としてフィプロニルおよび ピクロトキシニンの $\mathrm{IC}_{50}$ 值を用いた.

フィプロニルとピクロトキシニンの相互作用を各種濃度 のフィプロニルとピクロトキシニンを同時処理し，得られ た濃度依存曲線を 1 site model から得られた等式 (eq. 1), 2 site model から得られた等式（eq. 2) を用いて解析した (Fig. 8)。破線は 1 site model から得られた等式による曲線 を示し，実線は 2 site model から得られた等式による曲線 を示している．実験值は 2 site model から得られた理論曲 線に近かったことからフィプロニルとピクロトキシニンは 異なる部位に結合する可能性が示された。

\section{2. アニサチンとピクロトキシニンとの間の相互作用}

$\mathrm{GABA}_{\mathrm{A}} レ$ セプーにおけるアニサチンの結合部位を検 討するため，アニサチンとピクロトキシニンとの間の相互 作用を調べた.アニサチンおよびピクロトキシニンは共に $\mathrm{GABA}_{\mathrm{A}}$ レセプターに作用し，GABA 誘導性イオン電流を 抑制する化合物である。アニサチンとピクロトキシニンが 同一の結合部位に作用する可能性を検討するため，両化合 

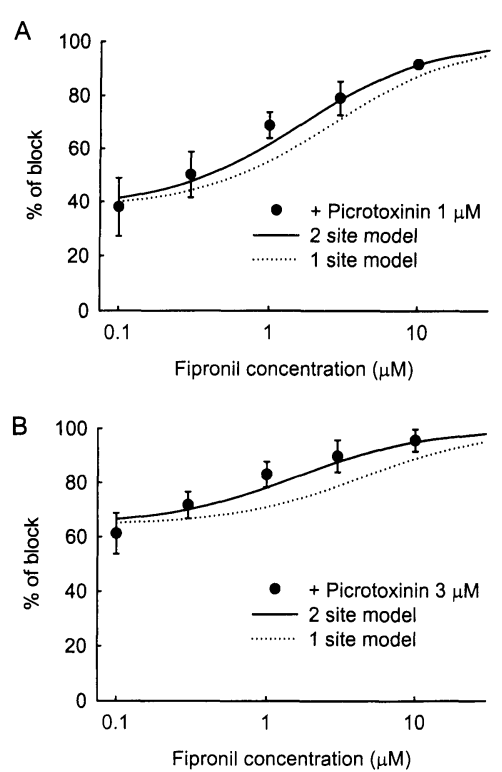

Fig. 8 The effect of picrotoxinin on fipronil suppression of GABA-induced currents in rat DRG neurons.

Dose-response relationships for fipronil suppression of GABA-induced currents were determined in the presence of $1 \mu \mathrm{M}(\mathrm{A})$ and $3 \mu \mathrm{M}(\mathrm{B})$ picrotoxinin. Picrotoxinin at $1 \mu \mathrm{M}$ caused $34.0 \pm 9.7 \%$ block of the current $(n=4)(A)$ and at 3 $\mu \mathrm{M}$ caused $51.8 \pm 2.1 \%$ block $(\mathrm{n}=4) \quad(\mathrm{B})$. Dose-response relationships in the presence of picrotoxinin were fitted by two equations described in the text. Dotted line depicts the fit of data with a logistic eq. 1 (one-site model). Solid line depicts the fit of data with a logistic eq. 2 (two-site model). The $\mathrm{K}_{\mathrm{P}}$ and $\mathrm{K}_{\mathrm{F}}$ values were set to 1.60 and $1.66 \mu \mathrm{M}$, respectively.

物を同時に処理した場合とピクロトキシニン単独処理の場 合とで薬量作用曲線を比較した. Fig. 9 にアニサチン $1 \mu \mathrm{M}$ 存在下 $(\bigcirc)$, またはアニサチンが存在しない状態でのピク ロトキシニンの薬量作用曲線 (の) を示している.アニサチ ンおよびピクロトキシニンが存在しない状態でのイオン電 流の大きさを $100 \%$ としてそれぞれの電流の大きさを標準 化した. ピクロトキシニンは GABA 誘導性イオン電流を 濃度依存的に抑制し, $\mathrm{IC}_{50}$ 值は $0.42 \pm 0.04 \mu \mathrm{M}$ であった ${ }^{10)}$. アニサチン $1 \mu \mathrm{M}$ を加えてピクロトキシニンの作用を測定 した結果，ピクロトキシニンの濃度が低い場合はアニサチ ンはイオン電流を約 50\%抑制した.しかし, ピクロトキシニ ンが高濃度の場合, アニサチンによる作用はほとんどみら れず, ピクロトキシン単独の場合と同等の抑制度を示した. このことから，アニサチンはピクロトキシニンと相互作用 を示し，アニサチンとピクロトキシニンは結合部位を共有 していることが示唆された。

以上の結果から，ピクロトキシニンとアニサチンは同一 部位に結合するが，フィプロニルは異なる部位に結合する 可能性が示された。しかし，過去の報告ではフィプロニル はピクロトキシニンと同一部位に作用することが示されて

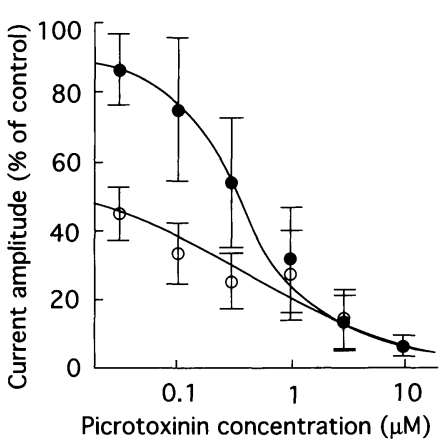

Fig. 9 The effect of $1 \mu \mathrm{M}$ anisatin on picrotoxinin suppression of $30 \mu \mathrm{M}$ GABA-induced currents in rat DRG neurons. Picrotoxinin suppressed GABA-induced currents in a concentration-dependent manner with an $\mathrm{EC}_{50}$ estimated to be $0.42 \pm 0.04 \mu \mathrm{M}$ and Hill coefficient $0.89 \pm 0.05(O, n=5)$. Co-application of picrotoxinin and anisatin suppressed GABA-induced currents in a concentration-dependent manner $(\bigcirc, n=5)$.

いる ${ }^{16,17)}$.これら相反する結論について考察したい. 近年ピ クロトキシニンの結合部位が $\mathrm{GABA}_{\mathrm{A}} レ$ レプター上に複数 存在する可能性が報告されている ${ }^{18,19)}$. フィプロニルが一 方のピクロトキシニン結合部位のみに作用し, 他方の結合 部位に作用しないと仮定した場合，両化合物は相互作用を 示さないという結果が得られるのではないかと考えられ る.なぜならば電気生理学的手法では化合物の相互作用を 直接化合物の結合としてとらえるのではなく，化合物の結 合の結果引き起こされる電流の変化としてとらえるためで ある.さらにフィプロニルとピクロトキシニンは別の部位 に結合するという報告もあり ${ }^{20,21)}$ ，これらの化合物の結合 部位に関する問題は今後も検討する余地がある.

\section{カルタップおよびニテンピラムの nACh レセプターに対する作用}

ラット褐色細胞腫由来 PC12 培養細胞の nACh レセプ ターに対するカルタップの作用をシングルチャネル法を用 いて検討した。シングルチャネル電流はセルアタッチ法に より測定し, 電流伝導, 開時間, 閉時間および, バースト 持続時間について解析した. カルタップ処理により $\mathrm{ACh}$ 誘導性イオン電流の開時間およびバースト持続時間は濃度 依存的に減少した ${ }^{22)}$.また, 電流伝導度は変化しなかったこ とから, カルタップの nACh レセプタ一抑制機構は主に開 時間の減少であることが判明した。

同様にニテンピラムの作用を検討した. ニテンピラム単 独処理により複数のコンダクタンスを持つシングルチャネ ル電流を発生させたことから，ニテンピラムは AChレセ プターに対してアゴニストとして作用していることが示さ れた ${ }^{23)}$. ニテンピラムを $\mathrm{ACh}$ と同時に処理したところ, メ インコンダクタンス電流の発生頻度は減少し, サブコンダ 
クタンス電流の発生頻度は増加した。またニテンピラム はチャネル開頻度を低下させた。以上のことから，ニテン ピラムは単独ではアゴニストとして, $\mathrm{ACh}$ 存在下ではアン タゴニストとして作用することが明かとなった。

\section{おわりに}

シングルチャネル電流を解析した結果, フィプロニル, アニサチン，ディルドリン，およびピクロトキシニンは GABA 誘導性イオン電流をチャネルの開確率を減少させ て抑制することが判明した。このことからこれら化合物 の作用は類似していると考えられる.フィプロニルとピク ロトキシンは相互作用を示さなかったことから，異なる部 位に結合する可能性が示された。しかし先にも述べたよう に，本研究の結果は電気生理学的手法を用いて得られたこ と，過去の報告による複数のピクロトキシン結合部位存在 の可能性，さらにフィプロニルはピクロトキシン結合部位 に作用しないことを示唆する研究結果が報告されているこ とも考え合わせると，結合部位に関してはさらに検討する 必要があると考えられる。

本研究では殺虫剤フィプロニル，天然毒アニサチン，従 来型の殺虫剤ディルドリンの作用機構を検討し，これまで に多くの知見が得られているピクロトキシニンと比較し た。イオンチャネルを作用点とする殺虫剤の中にも，作用 点におけるアミノ酸変化が抵抗性発達の原因となった例が あり，ディルドリンに対する抵抗性機構はこの代表的な例 と言える。フィプロニルはディルドリン抵抗性害虫に対し ても殺虫効果を示す ${ }^{24)}$. 本研究では作用機構が未知である 天然有毒成分アニサチンについて，イオンチャネルレベル で作用機構を解明した。これは，新たな作用機構の有用化 合物を探索する可能性を持ち，殺虫剤を含めた様々な化合 物とフィプロニルの作用機構を比較することは，抵抗性害 虫に対しても有効な殺虫剤開発の基礎研究として位置づけ られる。

近年では分子生物学的手法を使った薬剤の作用点探索も 盛んに行われている．例えば，イオンチャネルの特定のア ミノ酸を他のアミノ酸に置換すると薬剤の作用性が変化す ることから，分子レベルで薬剤の作用に関与している部位 を推察ことが可能となった．しかし，機能タンパクである イオンチャネルを立体的かつ動的な視点からとらえようと する場合，一部のアミノ酸の変化が全体の機能にどのよう に影響しているのかを解析することは未だ困難な問題であ る.パッチクランプ法を用いた研究においては，薬剂の作 用により引き起こされるチャネル機能変化を経時的に解析 することが可能であり，動的な千ャネル変化をとらえられ るという点において将来的にも期待される.
本研究を行うにあたり，筑波大学教授, 河野義明博士, 助教授, 本田洋助博士, 助教授, 戒能洋一助博士, Demar Taylar 博士に は，日頃から多大な御支援と御指導を賜りました. 正野俊夫博士 には筑波大学教授在職中様々な面で御支援と御指導を頂きまし た. 厚くお礼申し上げます。また，本研究を行うにあたり終始御 指導, 御鞭撻を賜りました，ノースウエスタン大学医学部, 栖橋 敏夫教授に心からお礼申し上げます。ノースウエスタン大学医 学部, 永田啓一博士には, 研究を進めていく上で的確なご指導を 賜りました。ノースウエスタン大学医学部教授，Jay Z. Yeh 博 士，同研究員 William Marszalec 博士，Xilong Zhao 博士には, ノースウエスタン大学留学中, 様々な面で御助言, 御指導を頂き ました. 島根大学生物資源科学部, 尾添嘉久教授には, 研究を進 めるにあたり多くの御助言頂き心から感謝申し上げます。学位 論文審査を進めるに当たり御指導頂きました，筑波大学農林学 系, 柿鴧眞教授, 応用生物化学系, 臼井健二教授に御礼申し上げ ます。

\section{引 用 文 献}

1) E. Neher and B. Sakmann: Nature 260, 799-802 (1976).

2) T. Ikeda, X. Zhao, K. Nagata, Y. Kono, T. Shono, J. Z. Yeh and T. Narahashi: J. Pharmacol. Exp. Ther. 296, 914921 (2001).

3) G. H. Dillon, W. B. Im, D. B. Carter and D. D. McKinley: Br. J. Pharmacol. 115, 539-545 (1995).

4) I. Kouno, N. Baba, M. Hashimoto, N. Kawano, M. Takahashi, H. Kaneto, C.-S. Yang and S. Sato: Chem. Pharm. Bull. 37, 2448-2451 (1989).

5) J. F. Lane, W. T. Koch, N. S. Leeds and G. Gorin: J. Amer. Chem. Soc. 74, 3211-3215 (1952).

6) T. Ikeda, K. Nagata, H. Honda, T. Shono and T. Narahashi: Pestic. Sci. 52, 337-342 (1998).

7) D. R. Curtis, J. Davies, C. J. A. Game, G. A. R. Johnston and R. M. McCulloch: Brain Res. 63, 419-423 (1973).

8) Y. Kudo, J. Oka and K. Yamada: Neurosci. Lett. 25, 83-88 (1981).

9) H. Shinozaki, M. Ishida and Y. Kudo: Brain Res. 222, 401-405 (1981).

10) T. Ikeda, Y. Ozoe, E. Okuyama, K. Nagata, H. Honda, T. Shono and T. Narahashi: Br. J. Pharmacol. 127, 1567-1576 (1999).

11) R. L. Macdonald and R. E. Twyman: "Ion Channels 3," ed. by T. Narahashi, Plenum Press, New York, pp. 315-343, 1992.

12) T. Ikeda, K. Nagata, T. Shono and T. Narahashi: NeuroReport 9, 3189-3195 (1998).

13) L. M. Cole and J. E. Casida: Pestic. Biochem. Physiol. 44, 1-8 (1992).

14) L. J. Lawrence and J. E. Casida: Life Sci. 35, 171-178 (1984).

15) K. Nagata and T. Narahashi: J. Pharmcol. Exp. Ther. 269, 164-171 (1994).

16) L. M. Cole, R. T. Roush and J. E. Casida: Life Sci. 56, 757-765 (1995).

17) A. M. Hosie, H. A. Baylis, S. D. Buckingham and D. B. Sattelle: Br. J. Pharmacol. 115, 909-912 (1995).

18) T.-B. Li and R. A. Pearce: Soc. Neurosci. Abstr. 26, 236.8 (2000).

19) K.-W. Yoon, D. F. Covey and S. M. Rothman: J. Physiol. (Lond.) 464, 423-439 (1993). 
20) M. A. Wolff and V. P. M. Wingate: Invert. Neurosci. 3, 305315 (1998).

21) M. Kamijima and J. E. Casida: Toxicol. Appl. Pharmacol. 163, 188-194 (2000).

22) K. Nagata, T. Ikeda, E. Aoyama and T. Shono: J. Pesticide Sci. 23, 40-43 (1998).

23) K. Nagata, E. Aoyama, T. Ikeda and T. Shono: J. Pesticide Sci. 24, 143-148 (1999).

24) A. S. Moffat: Science 261, 550-551 (1993).

|||||||||||||||||||||||||||||||||||||||||||||||||||||||||||||||||||||||||||||||

Society Awards 2002

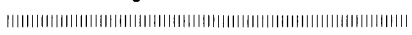

(on high prospectiveness)

\section{Electrophysiological Study of the Mechanism of Action of Insecticides Activity on Ion Channels}

\section{INTRODUCTUION}

Ion channels in the membrane play a very important role in nerve excitation and synaptic transmission. The nerve action potential is generated as a result of opening and closing of $\mathrm{Na}^{+}$and $\mathrm{K}^{+}$channels. When an action potential arrives at the nerve terminal, neurotransmitters such as $\gamma$-aminobutyric acid (GABA), acetylcholine $(\mathrm{ACh})$, and glutamate, are released from the presynaptic terminal, which in turn activate the respective postsynaptic receptor-channel. Many insecticides are known to act on receptors and channels. The $\mathrm{GABA}_{\mathrm{A}}$ receptor-channel is anion permeable, especially $\mathrm{Cl}^{-}$, and causes inhibition of synaptic transmission. On the other hand, the nicotinic acetylcholine receptor (nAChR) is cation permeable, and causes excitatory synaptic transmission. Both types of receptors comprise five subunits which form a channel at the center.

Several methods are available for the study of the mechanism of action of chemicals on the nervous system: by measuring fluxes of radio labeled ions; by measuring radioligand binding; and by recording ionic currents with electrophysiological methods. The interactions of chemicals with ion channels can be measured most efficiently by electrophysiological methods, as most ion channel functions occur within milliseconds. One of the most powerful electrophysiological methods is patch clamp developed in 1976 as a variation of the voltage clamp method. Patch clamp allows us to measure the channel activity of the entire cell membrane (whole-cell patch clamp) or the activity of single channels (singlechannel patch clamp).

This study is focused on the chemicals that inhibit GABA receptors including the phenylpyrazole insecticide fipronil, the cyclodiene insecticide dieldrin, and natural toxins anisatin and picrotoxinin, and is aimed at elucidating their mechanism of action on the $\mathrm{GABA}_{\mathrm{A}}$ receptor using patch clamp techniques. This study also covers the mechanism of action of cartap and nitenpyram on nAChRs.

\section{EFFECT OF FIPRONIL ON GABA ${ }_{\mathrm{A}}$ RECEPTOR}

Fipronil is the first phenylpyrazole insecticide introduced for pest control. It is effective against some insects that have become resistant to the existing insecticides. In order to elucidate the mechanism of fipronil action, whole-cell patch clamp experiments were performed using rat dorsal root ganglion neurons in primary culture. The suppression of the $\mathrm{GABA}_{\mathrm{A}}$ receptor by bath application of $1 \mu \mathrm{M}$ fipronil was assessed by a brief $(10 \mathrm{msec})$ application of $300 \mu \mathrm{M}$ GABA. The peak current amplitude gradually decreased to $66.1 \pm 8.1 \%$ of the control, and a complete recovery of currents was observed after washout with fipronil-free solution. To examine whether fipronil inhibition of GABA-induced currents requires the opening of channels, experiments were carried out by pre-application of fipronil without GABA applications. The first test current amplitude after 15 min pre-application of fipronil in the bath was reduced to $68.4 \pm 9.3 \%$ of control. Thus, the suppression of GABA-induced current by fipronil does not require the opening of channels.

A simple model was proposed for fipronil interactions with the $\mathrm{GABA}_{\mathrm{A}}$ receptor in both resting and activated states. According to this model, the time constant $(\tau)$ for the onset of block is equal to $1 /\left(\mathrm{k}_{+1}[\mathrm{~F}]+\mathrm{k}_{-1}\right)$, where $[\mathrm{F}]$ is the fipronil concentration, $\mathrm{k}_{+1}$ and $\mathrm{k}_{-1}$ are drug association and dissociation rates, respectively. Fipronil suppression on the resting $\mathrm{GABA}_{\mathrm{A}}$ receptor was monitored by $10 \mathrm{msec}$ test pulses of GABA. In order to 
obtain $\mathrm{k}_{+1}$ and $\mathrm{k}_{-1}$, the change in peak current amplitude was plotted as a function of fipronil incubation period, and the plots were fitted with a single exponential function. The $\tau$ values were $74.9 \pm 13.9,45.0 \pm 4.5,34.9 \pm$ 1.4 , and $27.4 \pm 0.68 \mathrm{sec}$ in the presence of $1,3,10$, and 30 $\mu \mathrm{M}$ fipronil, respectively. The plot of $1 / \tau$ vs fipronil concentration yielded a $\mathrm{k}_{+1}$ of $673 \pm 220 \mathrm{M}^{-1} \mathrm{sec}^{-1}$, a $\mathrm{k}_{-1}$ of $0.018 \pm 0.0035 \mathrm{sec}^{-1}$. To examine the fipronil block of the activated $\mathrm{GABA}_{\mathrm{A}}$ receptor, various concentrations of fipronil were co-applied with GABA. In order to obtain $\mathbf{k}^{\prime}{ }_{+1}$ and $\mathbf{k}^{\prime}{ }_{-1}$, current decay was fitted with a single exponential function. The $\tau$ values were 11.09 \pm $3.66,10.10 \pm 3.83,7.16 \pm 0.71,5.48 \pm 1.19$, and $3.38 \pm 0.69$ $\mathrm{sec}$ in the presence of fipronil at $0,1,3,10$, and $30 \mu \mathrm{M}$, respectively. The plot of $1 / \tau$ vs fipronil concentration was fitted with the equation of a linear regression. I obtained a value of $6600 \pm 380 \mathrm{M}^{-1} \mathrm{sec}^{-1}$ for $\mathrm{k}_{+1}^{\prime}$, and $0.11 \pm 0.0054 \mathrm{sec}^{-1}$ for $\mathrm{k}^{\prime}{ }_{-1}$ for fipronil block of the activated receptor. It is concluded that although fipronil suppresses GABA induced currents without channel activation, channel opening facilitates fipronil binding to and unbinding from the receptor.

\section{THE EFFECT OF ANISATIN ON GABA $_{A}$ RECEPTOR}

Anisatin, a toxic, insecticidally active component of Sikimi plant, is known to act on the GABA system. In order to elucidate the mechanism of anisatin interaction with the GABA system, whole-cell patch clamp experiments were performed with rat dorsal root ganglion neurons in primary culture. The currents induced by 30 $\mu \mathrm{M}$ GABA were suppressed when $1 \mu \mathrm{M}$ anisatin was co-applied. The peak current amplitude gradually decreased to $58.3 \%$ of the control during repeated coapplications. No recovery of currents was observed after washout with anisatin-free solution. To examine whether anisatin inhibition of GABA-induced currents requires the GABA-induced opening of channels, experiments were carried out by pre-application of anisatin without GABA application. Pre-application of $1 \mu \mathrm{M}$ anisatin alone for $60 \mathrm{sec}$ had no effect on GABA-induced currents. The results indicate that the anisatin-induced suppression of GABA-induced currents requires conformational changes associated with the opening of channels.

\section{THE EFFECTS OF CHEMICALS ON GABA-INDUCED SINGLE-CHANNEL CURRENTS}

To elucidate the more detailed mechanisms of fipronil, anisatin, dieldrin and picrotoxinin interaction with the $\mathrm{GABA}_{\mathrm{A}}$ receptor, single-channel patch clamp experiments were performed using rat dorsal root ganglion neurons. Single-channel currents were recorded using the outside-out membrane patch configuration. When $10 \mu \mathrm{M}$ GABA was applied to the bath, inward single- channel currents occurred at a holding potential of -60 $\mathrm{mV}$. The main conductance of currents induced by 10 $\mu \mathrm{M}$ GABA was estimated to be $27.2 \pm 4.3 \mathrm{pS}$. In order to examine modulation of fipronil, anisatin, dieldrin, and picrotoxinin on GABA-induced single-channel currents, $10 \mu \mathrm{M}$ GABA was co-applied with $10 \mu \mathrm{M}$ fipronil, $1 \mu \mathrm{M}$ anisatin, $0.1 \mu \mathrm{M}$ dieldrin, or $0.4 \mu \mathrm{M}$ picrotoxinin. The main conductances in the presence of $10 \mu \mathrm{M} \mathrm{GABA}$ plus fipronil, anisatin, dieldrin, and picrotoxinin were estimated to be $26.1 \pm 4.1,26.0,25.9 \pm 1.5$, and $26.7 \pm 1.3 \mathrm{pS}$, respectively. These values were almost the same as that in the presence of $10 \mu \mathrm{M}$ GABA alone. Thus, these chemicals do not affect the single-channel main conductance. Fipronil, anisatin, dieldrin, and picrotoxinin prolonged the mean closed time, resulting in the reduction of the frequency of channel openings in a similar manner. Thus, these chemicals have a common mechanism to suppress the GABA-induced whole-cell currents. In addition, fipronil and dieldrin slightly decreased the mean open time. This effect also contributed in part to the suppression of GABA-induced whole-cell currents.

\section{SITE OF ACTION OF FIPRONIL AND ANISATIN}

Two models for fipronil and picrotoxinin interactions at the $\mathrm{GABA}_{\mathrm{A}}$ receptor are proposed, one-site model and two-site model. In one-site model, fipronil and picrotoxinin compete with each other for the same binding site. For two-site model, fipronil and picrotoxinin have their own binding sites, and they can independently bind to the respective binding site to inhibit GABA-induced current. The dose-dependent suppression of GABAinduced current by fipronil in the presence of picrotoxinin was analyzed by two equations, one for one-site model (eq. 1) and the other for two-site model (eq. 2):

$$
\begin{aligned}
\mathrm{RP}+\mathrm{RF}= & \mathrm{R}_{\mathrm{T}}\left([\mathrm{P}] / \mathrm{K}_{\mathrm{P}}+[\mathrm{F}] / \mathrm{K}_{\mathrm{F}}\right) /(1+[\mathrm{P}] \\
\left./ \mathrm{K}_{\mathrm{P}}+[\mathrm{F}] / \mathrm{K}_{\mathrm{F}}\right) & \text { (eq. 1) } \\
\mathrm{RP}+\mathrm{RF}+\mathrm{RPF}= & \mathrm{R}_{\mathrm{T}}\left([\mathrm{P}] / \mathrm{K}_{\mathrm{P}}+[\mathrm{F}] / \mathrm{K}_{\mathrm{F}}+[\mathrm{P}][\mathrm{F}]\right. \\
& \left./ \mathrm{K}_{\mathrm{P}} \mathrm{K}_{\mathrm{F}}\right) /\left(1+[\mathrm{P}] / \mathrm{K}_{\mathrm{P}}\right. \\
& \left.\left.+[\mathrm{F}] / \mathrm{K}_{\mathrm{F}}+[\mathrm{P}][\mathrm{F}] / \mathrm{K}_{\mathrm{P}} \mathrm{K}_{\mathrm{F}}\right) \text { (eq. } 2\right)
\end{aligned}
$$

In order to determine the site of action of fipronil on the $\mathrm{GABA}_{\mathrm{A}}$ receptor, competition experiments were performed using picrotoxinin. Picrotoxinin at 1 or $3 \mu \mathrm{M}$ was applied to the bath solution together with various concentrations of fipronil. Dose-response relationships for fipronil suppression of GABA-induced currents with picrotoxinin are fitted by the above two equations 1 and 2. The dotted line depicts the fit of data with a logistic eq. 1 (one-site model), and the solid line depicts the fit of data with a logistic eq. 2 (two-site model). It is clear that two-site model gives better fitting to the data than one-site model. It is concluded that fipronil and picrotoxinin do not share a common binding site. Previous report suggests that fipronil and picrotoxinin share the same binding site on GABA receptor. This discrep- 
ancy remains to be solved.

In order to determine the site of action of anisatin, competition experiments were performed using picrotoxinin. When low concentrations of picrotoxinin (0.03$0.3 \mu \mathrm{M})$ were co-applied with $1 \mu \mathrm{M}$ anisatin, GABAinduced currents were suppressed to about $50 \%$ of the level achieved in the presence of picrotoxinin alone. However, when picrotoxinin concentration was high (3$10 \mu \mathrm{M})$, the suppressive effect was similar to that achieved by the co-application of picrotoxinin and $1 \mu \mathrm{M}$ anisatin. Thus, it is concluded that anisatin and picrotoxinin share a common binding site on the GABA receptor-channel complex.

\section{CARTAP AND NITENPYRAM MODULATION OF THE NICOTINIC ACETYLCHOLINE RECEPTOR- CHANNEL OF CLONAL RAT PC12 CELLS}

Cartap and nitenpyram are known to act on the nAChR. Effects of cartap and nitenpyram on the neuronal $n A C h R$ of clonal rat phaeochromocytoma (PC 12) cells were studied using the single-channel patch clamp method. When cartap was co-applied with ACh, singlechannel openings were shortened and occurred in bursts separated by brief closures or gaps. The current amplitudes in the presence of cartap were virtually identical to those of currents induced by ACh only. The mean open time and burst duration were significantly decreased in the presence of cartap in a dose-dependent manner. These changes of single-channel kinetics result in a significant decrease in total charge carried through the open $\mathrm{nAChR}$ channels explaining the suppressive effect of cartap on $\mathrm{nAChRs.}$

Nitenpyram itself induced single-channel currents mediated by the nAChR. Co-application of $\mathrm{ACh}$ and nitenpyram opened the channels exhibiting two conductance states. The proportion of main conductance levels was decreased and that of subconductance levels was increased in the presence of nitenpyram. The open time and closed time distributions, but not for the burst duration, for the main conductance state currents with co-application of $\mathrm{ACh}$ and nitenpyram were similar to those of ACh-induced current. These changes of singlechannel kinetics result in a decrease in probability of openings of main conductance state currents explaining the effects of nitenpyram on the neuronal nAChR. 